\title{
Differentiating Modes of Inquiry
}

\section{Clifford K Madsen*}

Robert O. Lawton Distinguished Professor of Music, USA

Submission: September 22, 2017; Published: October 23, 2017

*Corresponding author: Clifford K Madsen, Robert 0. Lawton Distinguished Professor of Music, USA, Email: cmadsen@admin.fsu.edu

\section{Introduction and Objectives}

Having taught college music students various aspects of experimental research grounded in acoustics (physics), it became readily apparent to me that I needed some sort of taxonomy in order to parse out aspects relating to oftencontradictory techniques encountered in formal music study; especially from the private studio. One recurring research finding concerning these music majors, is their earliest remembrances of music. Indeed, every student sampled described strong phenomenological "emotional feelings" associated with their earliest remembrances [1]. Furthermore, each person said that it was these experiences that directly contributed to their "love of music" and choosing it as a field of study. Phenomenal "experiences" as opposed to acoustics descriptions continue throughout music study with analogies and metaphors regularly found in the private study.

A singer evidencing constricted tone is told, "to imagine yourself hanging from a string completely suspended from the ceiling and totally relaxed." A trumpet player with unsteady pitch might be told, "to imagine blowing through the horn aiming at a big red target painted on the wall." A violinist is told "to make love to every note by drawing the entire bow throughout the complete phrase." Alternately, when these same students are studying acoustics and told that every single aspect of each pitch can be measured with extant equipment, and that the aforementioned analogies represent phenomenon that do not exist as empirical facts, some become understandably upset. This dichotomy starts very early in life as we realize the difficulty of describing those "peak" experiences that often accompany being totally consumed while listening to music, or viewing a painting or experiencing something extremely powerful when viewing the Sistine Chapel or experiencing the original David.

Rather than confronting students concerning these issues, I devised a taxonomy that parses out these differences as Modes of Inquiry [2]. In the following formulas for modes, the sign "/" indicates "exclusive from," the three dotted ".:" means "therefore," while parenthesis "( )" a "tentative hypothesis." For example, fruit/meat suggests that fruit exists exclusive from meat; an egg $\therefore$ chicken might mean that egg exists, therefore the chicken exists; and (given an effective umbrella) one will not get wet in the rain. Paraphrased in Table are the modes of inquiry (Table 1).

Table 1: Differentiating Modes of Inquiry.

\begin{tabular}{|c|c|c|}
\hline Hypothetical & $\begin{array}{c}\text { (A) B C } \therefore \\
\text { A or not/A }\end{array}$ & $\begin{array}{c}\text { (A) is hypothesized, B and C link } \\
\text { evidence to support A; therefore, } \\
\text { A is regarded as empirically } \\
\text { verifiable or is rejected }\end{array}$ \\
\hline Assumptive & A $\therefore$ B C & $\begin{array}{c}\text { A is a concept based on a priori- } \\
\text { authority or rule-based thinking; } \\
\text { B and C are sought to confirm A } \\
\text { without a verifiable empirical } \\
\text { link }\end{array}$ \\
\hline Phenomenological & A/B C & $\begin{array}{c}\text { A is a belief or concept firmly } \\
\text { held and the slash indicates } \\
\text { that no proof from B or C is } \\
\text { necessary }\end{array}$ \\
\hline
\end{tabular}

Where A means a belief, object, theory, or hypothesis

$\mathrm{B}, \mathrm{C}$ means proofs, behavioral observations, or experiences

I means exclusive from $\triangle$ means therefore

( ) means tentative hypothesis [(given an effective umbrella) one will not get wet in the rain].

If A is a belief that is held, the "Phenomenological person" might say that no empirical proof is necessary for the belief. The "Assumptive" person knows without a doubt that A is i.e., exists, and looks at the world for proof of A. This mode never rejects A regardless of empirical evidence. The "Hypothetical" person looks at the world and forms a hypothesis and based upon evidence either concludes A; or if not substantiated rejects "A".

For example, in explaining the existence of God, fundamental Christians, agnostics, atheist, and scientists often argue modes of inquiry. The religionist who states "I know God exists" is generally speaking from the Phenomenological or Assumptive mode of inquiry. The atheist who says, "I know that God does not exist," also is generally speaking from the Phenomenological or Assumptive mode of inquiry. This person who says, "God exists, just look at the beautiful trees, and the sunset and the universe, "might be speaking from the Assumptive mode of inquiry. This person begins with a belief A and looks for proof of that belief. 
This person is combining belief in God and proof for that belief $=\mathrm{A}$. the belief $\mathrm{A}$ is never rejected. On the question of empirical existence of God the "Hypothetical" or scientific mode of inquiry may lead to agnosticism as definite empirical proof of God may not be possible.

In the scientific mode of inquiry one seeks knowledge based on experimental methods. One seeks, but does not begin with "truth," only an operationally defined hypothesis (A). People switch among these modes of inquiry as they address different aspects of their person and professional lives. On some issues they operate in the hypothetical mode and demand empirical verification. On others, they operate in the assumptive mode and accept community agreement or authority (politics, religion, textbook science). On a few, they operate in the phenomenological mode (I know what I believe about God, and I do not need any proof.)
Providing this short differentiation allows everyone to feel comfortable in whatever belief(s) he or she may have. It also allows the study of music from an empirical basis providing the "freedom" of not getting inundated with religious or other a priori aspects when teaching acoustics and experimental research.

Beginning with the recognition of these different modes of inquiry the student realizes that it is okay to use analogies and metaphors toward a pedagogical goal without it being factually grounded in empirical fact-only clearly-defined empirical aspects can (and should) be investigated experimentally.

\section{References}

1. Madsen CK, Kelly SN (2002) First remembrances of wanting to become a music teacher. Journal of Research in Music Education 50: 323-332.

2. Madsen CK, Moore RS (1978) Experimental research in music: workbook in design and statistical tests, contemporary publishing company, USA.
This work is licensed under Creative Commons Attribution 4.0 License DOI: 10.19080/CTBEB.2017.09.555775
- Quality Editorial service

- Swift Peer Review

- Reprints availability

- E-prints Service

- Manuscript Podcast for convenient understanding

- Global attainment for your research

- Manuscript accessibility in different formats

( Pdf, E-pub, Full Text, Audio)

- Unceasing customer service

Track the below URL for one-step submission https://juniperpublishers.com/online-submission.php 